\title{
Ratooning Potential of Different Promising Sugarcane Clones under Varying Trench Spacing
}

\author{
Muhammad Aman Ullah Khan ${ }^{1 *}$, Muhammad Talha Aslam ${ }^{1}$, Abdul Rehman ${ }^{1}$, Muhammad Nawaz ${ }^{2}$, \\ Muhammad Jahanzaib Khan ${ }^{1}$, Muhammad Ahsin Ayub ${ }^{3}$, Arbaz Ahmad Khan ${ }^{1}$,Muhammad Adil Rehman ${ }^{1}$, \\ Bilal Ahmad Shahzad ${ }^{1}$, Sajid Hussain ${ }^{1}$, Muhammad Umair Hassan ${ }^{1}$ and Riaz Ahmad ${ }^{1}$
}

${ }^{1}$ Department of Agronomy, University of Agriculture, Faisalabad 38040, Pakistan; ${ }^{2}$ Department of Agricultural Engineering, Khwaja Fareed University of Engineering and Information Technology, Rahim Yar Khan 64200, Pakistan; ${ }^{3}$ Rice Research Station Bahawalnagar 62031, Pakistan.

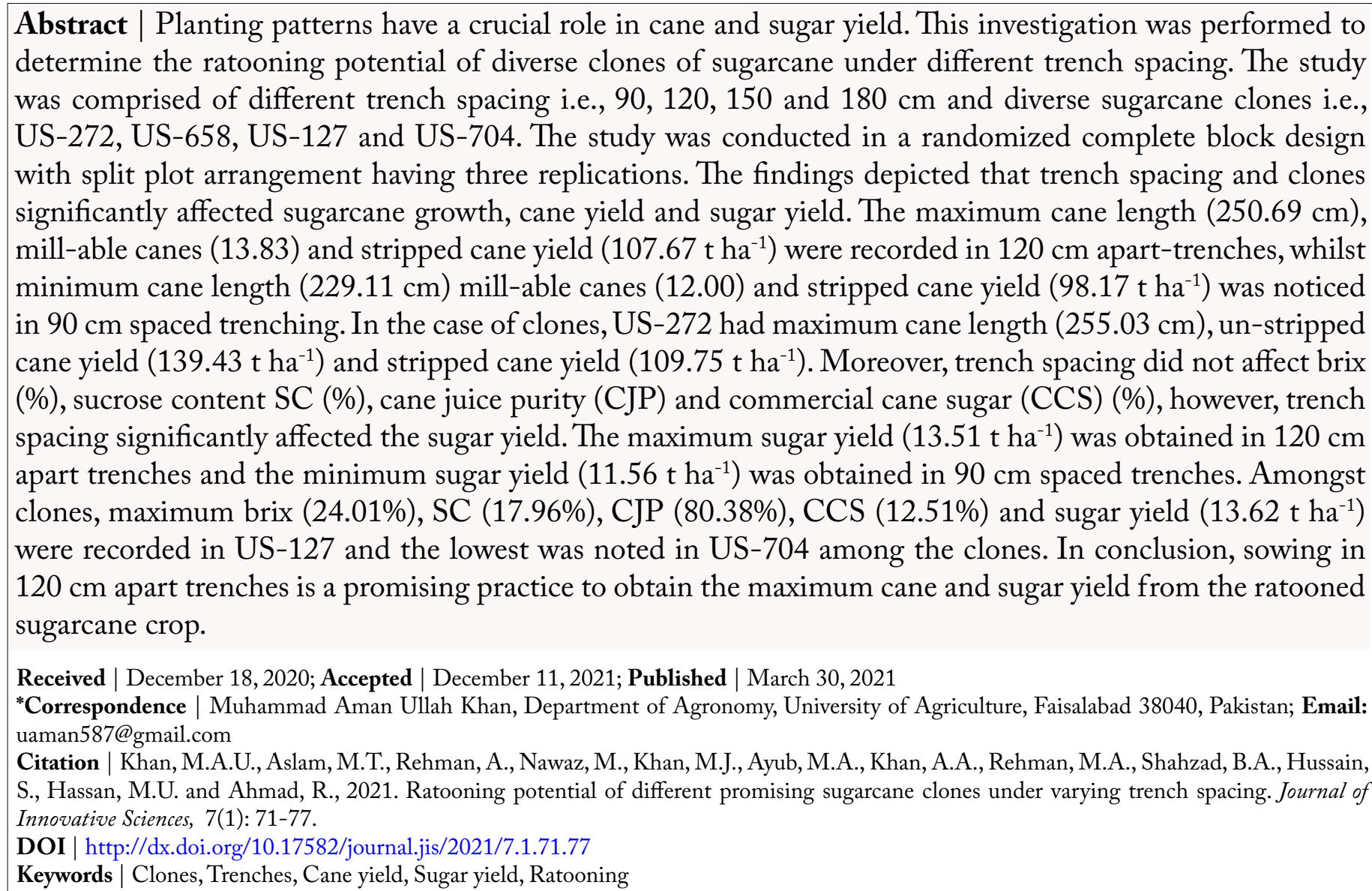

\section{Introduction}

Sugarcane is an imperious sugar crop of Pakistan and it has a contribution of $0.6 \%$ in GDP and $2.9 \%$ in the value added by the agriculture sector (GoP, 2020). Pakistan ranks at $5^{\text {th }}$ position regarding the area of production, whilst, it occupies $8^{\text {th }}$ position regarding the production amid the 104 sugarcane producing countries worldwide (FAO, 2017). The average sugarcane yield of Pakistan is $55.6 \mathrm{tha}^{-1}$ that is quite lower than other advanced countries i.e., Australia, Brazil, USA, China and India (FAO, 2017; 
Nawaz et al., 2017; GoP, 2017). The sugar industry in Pakistan is the second largest industry after the textile industry (Nawaz et al., 2019) and Pakistan is the $9^{\text {th }}$ largest sugarcane grower in the world (Chattha et al., 2017a).

Sowing methods play an important role in the growth and final production owing to fact they significantly affect germination and stand establishment (Chattha et al., 2017b). The traditional planting methods are the chief cause of the lower crop production (Hassan et al., 2019a; Chattha et al., 2020) and cane productivity in Pakistan (Aamer et al., 2017). Moreover, low plant population, plant lodging, thinner and dwarfed canes are considered to be the main causes of low production in conventional planting methods (Ehsanullah et al., 2011). Sugarcane cultivated by conventional planting method at $60-75 \mathrm{~cm}$ apart single enhance the number of plants per unit, however, in this method different management practices are very difficult to perform which are adequate for the proper and uniform stand establishment. Therefore, to ensure desired production and to meet the sugar needs planting methods should be optimized to minimize the gap between potential and actual yield. Lodging is considered as one of the severe problems of lower sugarcane production in Pakistan. The sugarcane yield, juice quality, and sugar recovery is considerably decreased due to crop lodging (Heerden et al., 2015). The wider row trenches have an appreciable potential to improve the sugarcane yield in Pakistan (Ullah et al., 2016). Sugarcane plantation in trenches by using the recommended seed rate is a more appropriate and effective method to obtain higher production compared to the conventional method (Bhullar et al., 2008).

The ratooning is a technique of raising a full crop of sugarcane from stubbles of the previous crop. Sugarcane ratoon crop is also very exhaustive crop like the main crop. The ratoon crop of sugarcane needs more nitrogen application because of immobilization, shallow and decayed older roots of ratoon. Therefore, in ratoon crop 20 to $30 \%$ more nitrogen should be used as compared to the main crop (Lal and Singh, 2008). The ratooning of sugarcane is considered more economical because it does not need any seed and it saves the planting operations. The ratoon crop of sugarcane also prolongs the crushing time period of sugar mills because it matures early than the main sugarcane crop. Nonetheless, the ratoon crop has less production than the main crop (Shukla et al., 2013).
The selection and cultivation of suitable cultivars play a crucial role in the final yield and biomass production (Hassan et al., 2018; 2019a; 2020). Likewise, the cultivation of appropriate sugarcane genotypes also plays an appreciable role in the final cane and sugar yield. Singh and Dey (2002) observed the clear difference among the clones for growth, cane yield and final sugar yield. The ratooning is considered to be the behavior of genotype and environment. Therefore, it is mandatory to identify genotypes with good ratooning abilities. Therefore, the current study was performed to determine the ratooning ability of various sugarcane clones under different trench spacing.

\section{Material and Methods}

\subsection{Experimental site, soil and climatic conditions}

This study was performed at the Agronomic Research Area of the University of Agriculture Faisalabad during 2016-2017. The study site falls in semi-arid region, whilst, other weather conditions during the growing period are given in Table 1 . The soil samples were taken from various points of the field with the soil auger, homogenized and analyzed to determine the various soil physical and chemical properties (Homer and Pratt, 1961). The soil had $\mathrm{pH} 7.83$, organic matter $0.76 \%$, total nitrogen $(\mathrm{N})$ $0.014 \%$, extractable phosphorus (P) $6.33 \mathrm{ppm}$ and exchangeable potassium (K) 181 ppm, respectively.

\begin{tabular}{|c|c|c|c|}
\hline Months & $\begin{array}{l}\text { Monthly average } \\
\text { temperature }\left({ }^{\circ} \mathbf{C}\right)\end{array}$ & $\begin{array}{l}\text { Relative } \\
\text { humidity }\end{array}$ & $\begin{array}{l}\text { Rainfall } \\
(\mathrm{mm})\end{array}$ \\
\hline Sep-16 & 31 & 53.6 & 12 \\
\hline Oct-16 & 26.7 & 51.3 & 22.2 \\
\hline Nov-16 & 20.1 & 60.1 & 0 \\
\hline Dec-16 & 16.4 & 68.7 & 0 \\
\hline Jan-17 & 12.9 & 72 & 11.5 \\
\hline Feb-17 & 16.8 & 53 & 4.1 \\
\hline Mar-17 & 20.7 & 49.5 & 16.2 \\
\hline Apr-17 & 29.3 & 30.6 & 28.3 \\
\hline May-17 & 33.5 & 29.8 & 10.1 \\
\hline June-17 & 33.5 & 44.5 & 41.6 \\
\hline July-17 & 33.7 & 70 & 117.2 \\
\hline Aug-17 & 33.4 & 68.9 & 66 \\
\hline Sep-17 & 30.5 & 67,5 & 35.6 \\
\hline
\end{tabular}

\subsection{Crop husbandry}

The soil was ploughed three times and planked to 
prepare the seedbed for the sowing of main sugarcane crop. The net plot size was $12 \mathrm{~m}$ x $3.6 \mathrm{~m}$ for $0.9 \mathrm{~m}$ apart trenches, and for $1.5 \mathrm{~m}$ and $1.8 \mathrm{~m}$ apart trenches the net plot size was $12 \mathrm{~m} \times 9 \mathrm{~m}$. The sowing was done using 75000 double budded setts per hectare. The sugarcane clones i.e., US-272, US-127, US-658 and US-704 were kept in subplots while, trench spacing viz. $90 \mathrm{~cm}, 120 \mathrm{~cm}, 150 \mathrm{~cm}$ and $180 \mathrm{~cm}$ apart trenches were kept in the main plot. Fertilizers (NPK) were used at rate of $218-145-145 \mathrm{~kg} \mathrm{ha}^{-1}$. The sources of NPK fertilizers were; urea $(46 \% \mathrm{~N})$, di-ammonium phosphate $(46 \% \mathrm{P}$ and $18 \% \mathrm{~N})$ and suphate of potash $(50 \% \mathrm{~K}) .50 \% \mathrm{~N}$ and $100 \% \mathrm{~K}$ and $\mathrm{P}$ was applied at sowing and the remaining $50 \% \mathrm{~N}$ used in two splits. Irrigation was given to crop as and when needed and total 16 irrigations were applied. All the other management practices were kept uniform to ensure good stand establishment.

\subsection{Field measurements and qualitative analysis}

Ten plants from every plot were selected; plant height and cane length was measured and averaged. Similarly, millable canes were counted by selecting an area of 1 $\mathrm{m}^{2}$ from each plot. Total canes from each plot were harvested and weighed to determine the un-stripped cane yield, thereafter, tops and trash were removed from canes and weighed to determine the stripped cane yield (SCY). The brix concentration, sucrose contents (SC), cane juice purity (CJP), commercial cane sugar (CCS) were determined by the standard procedures of Spancer and Meade (1963). Moreover, total sugar yield was calculated by the following formula.

$$
\text { Total sugar yield }=\frac{\text { Stripped cane yield } t \text { ha }-1 \times C S R \%}{10}
$$

\subsection{Experimental design and statistical analysis}

The study was conducted in RCBD in a split arrangement with three replications. The data on different characters were analyzed by Fisher's analysis of variance technique and LSD test was performed at $5 \%$ probability level to separate the treatment means (Steel et al., 1997).

\section{Results and Discusiion}

The findings showed of diverse trench spaces significantly affected the plant height, can length and millable canes (Table 2). The taller plants (436 $\mathrm{cm})$ were noticed in $150 \mathrm{~cm}$ apart trenches, whilst the shortest plants $(416 \mathrm{~cm})$ were noted in $90 \mathrm{~cm}$ apart trenches (Table 2). Likewise, trench spacing also significantly affected the unstripped and stripped cane yield (SCY). Sowing in $150 \mathrm{~cm}$ apart trenches remained at top ranking with maximum un-striped yield (138.79 $\mathrm{t} \mathrm{ha}^{-1}$ ), while sowing in 120 spaced tranches remained at the top position with maximum SCY (107.67 t ha $\left.{ }^{-1}\right)$, which was also comparable with the $150 \mathrm{~cm}$ apart trenches. Moreover, the lowest unstripped cane yield (127.67 $\left.\mathrm{t} \mathrm{ha}^{-1}\right)$ and SCY (98.17 $\mathrm{t} \mathrm{ha} \mathrm{a}^{-1}$ ) were obtained in $90 \mathrm{~cm}$ apart trenches (Table 2).

In the case of clones the taller plants $(443.08 \mathrm{~cm})$ were recorded for US-127, followed by US-272, whereas the shortest plants (411.25) were recorded for US-704. Clone US-272 remained at top position with maximum cane length $(255.03 \mathrm{~cm})$ after that US-127 that was comparable with US-272 and US658. Likewise, the maximum millable cane (13.41) was recorded in US-127, whereas the minimum millable canes (12.25) were recorded for US-704. Moreover, maximum unstripped cane yield (139.43 $\mathrm{t} \mathrm{ha}^{-1}$ ) and SCY (109.75 $\mathrm{t} \mathrm{ha}^{-1}$ ) were produced by US-272, followed by US-127, whereas the minimum unstripped cane yield (128.13 $\left.\mathrm{tha}^{-1}\right)$ and SCY (96.76 $\mathrm{t} \mathrm{ha}^{-1}$ ) were recorded for US-704 (Table 2).

The results indicated that trench spacing had a non-significant effect on the quality attributes, i.e., brix, SC, CJP and CCS while trench spacing had a significant impact on the total sugar yield (Table 3). The maximum sugar yield $\left(13.51 \mathrm{tha}^{-1}\right)$ was recorded in $120 \mathrm{~cm}$ apart trenches that were comparable with $150 \mathrm{~cm}$ spaced trenches and minimum sugar yield (11.56 t ha $\left.{ }^{-1}\right)$ was obtained from 90 spaced trenches. Conversely, clones had a significant impact on the qualitative attributes. The maximum brix (24.01\%) and SC (17.96\%) were noted in US-127, followed by US-658, whereas lowest brix $(22.57 \%)$ and SC (17.46\%) were noticed in US-704 (Table 3). Likewise, maximum CJP (80.38\%), CCS (12.51\%) was also recorded for US-127 that was comparable with the US-272, whereas the minimum CJP (72.86\%), CCS (10.74\%) was noted in US-704 (Table 3). Moreover, maximum sugar yield (13.62 $\left.\mathrm{t} \mathrm{ha}^{-1}\right)$ was noted in US-127, which was comparable with US-272 while minimum sugar yield $\left(10.89 \mathrm{t} \mathrm{ha}^{-1}\right)$ was noticed in US-704 (Table 3).

This study was done to determine the impact of trench spacing and clones on the ratooned crop of sugarcane. 
Table 2: Effect of tranche spacing and clones on growth, yield and yield related characters.

\begin{tabular}{|c|c|c|c|c|c|}
\hline $\begin{array}{l}\text { Trench spacing } \\
\text { (TS) }\end{array}$ & $\begin{array}{l}\text { Plant height } \\
\text { (cm) }\end{array}$ & $\begin{array}{l}\text { Cane length } \\
(\mathrm{cm})\end{array}$ & millable canes & $\begin{array}{l}\text { Un-Stripped cane } \\
\text { yield }\left(\mathrm{tha}^{-1}\right)\end{array}$ & $\begin{array}{l}\text { Stripped cane yield } \\
\left(\mathrm{tha}^{-1}\right)\end{array}$ \\
\hline $90 \mathrm{~cm}$ & $415.58 \mathrm{C}$ & $229.11 \mathrm{~B}$ & $12.00 \mathrm{C}$ & $127.66 \mathrm{C}$ & $98.17 \mathrm{C}$ \\
\hline $120 \mathrm{~cm}$ & $426.92 \mathrm{~B}$ & $250.69 \mathrm{~A}$ & $13.83 \mathrm{~A}$ & $136.58 \mathrm{~A}$ & $107.67 \mathrm{~A}$ \\
\hline $150 \mathrm{~cm}$ & $436.00 \mathrm{~A}$ & $237.48 \mathrm{~B}$ & $12.83 \mathrm{~B}$ & $138.79 \mathrm{~A}$ & $104.67 \mathrm{AB}$ \\
\hline $180 \mathrm{~cm}$ & $420.17 \mathrm{BC}$ & $235.69 \mathrm{~B}$ & $12.41 \mathrm{BC}$ & $130.95 \mathrm{~B}$ & $102.18 \mathrm{BC}$ \\
\hline $\mathrm{LSD} \leq 0.05 \mathrm{P}$ & 6.87 & 11.95 & 0.81 & 2.45 & 4.80 \\
\hline \multicolumn{6}{|l|}{ Clones (C) } \\
\hline US-272 & $430.08 \mathrm{~B}$ & $255.03 \mathrm{~A}$ & $13.08 \mathrm{~A}$ & $139.43 \mathrm{~A}$ & $109.75 \mathrm{~A}$ \\
\hline US-658 & $414.25 \mathrm{C}$ & $239.58 \mathrm{~B}$ & $12.33 \mathrm{~B}$ & $132.16 \mathrm{~B}$ & $100.83 \mathrm{C}$ \\
\hline US-127 & $443.08 \mathrm{~A}$ & $241.50 \mathrm{~B}$ & $13.41 \mathrm{~A}$ & $134.25 \mathrm{~B}$ & $105.33 \mathrm{~B}$ \\
\hline US-704 & $411.25 \mathrm{C}$ & 216.27 B & $12.25 \mathrm{~B}$ & $128.13 \mathrm{C}$ & $96.76 \mathrm{C}$ \\
\hline $\mathrm{LSD} \leq 0.05 \mathrm{P}$ & 10.30 & 7.56 & 0.66 & 2.68 & 4.22 \\
\hline $\mathrm{TS} \times \mathrm{C}$ & NS & NS & NS & NS & NS \\
\hline
\end{tabular}

The mean values sharing different letters differed at $0.05 \%$ probability level.

Table 3: Effect of tranche spacing and clones on qualitative attributes.

\begin{tabular}{|c|c|c|c|c|c|}
\hline Trench spacing (TS) & Brix (\%) & Sucrose (\%) in juice & $\begin{array}{l}\text { Cane juice purity } \\
\text { (\%) }\end{array}$ & $\begin{array}{l}\text { Commercial cane } \\
\text { sugar }(\%)\end{array}$ & $\begin{array}{l}\text { Total sugar yield } \\
\left(\mathrm{tha}^{-1}\right)\end{array}$ \\
\hline $90 \mathrm{~cm}$ & 22.99 & 17.40 & 76.68 & 11.63 & $11.56 \mathrm{C}$ \\
\hline $120 \mathrm{~cm}$ & 23.12 & 17.42 & 77.48 & 11.76 & $13.51 \mathrm{~A}$ \\
\hline $150 \mathrm{~cm}$ & 23.10 & 17.35 & 76.62 & 11.60 & $12.88 \mathrm{~A}$ \\
\hline $180 \mathrm{~cm}$ & 23.40 & 17.17 & 75.94 & 11.22 & $12.67 \mathrm{~B}$ \\
\hline $\mathrm{LSD} \leq 0.05 \mathrm{P}$ & NS & NS & NS & NS & 0.43 \\
\hline \multicolumn{6}{|l|}{ Clones (C) } \\
\hline US-272 & $23.04 \mathrm{~B}$ & $17.79 \mathrm{~A}$ & $79.86 \mathrm{~A}$ & $11.88 \mathrm{~B}$ & $13.25 \mathrm{AB}$ \\
\hline US-658 & $22.99 \mathrm{~B}$ & $17.96 \mathrm{~A}$ & $73.62 \mathrm{~B}$ & $11.09 \mathrm{C}$ & $12.86 \mathrm{~B}$ \\
\hline US-127 & $24.01 \mathrm{~A}$ & $17.96 \mathrm{~A}$ & $80.38 \mathrm{~A}$ & $12.51 \mathrm{~A}$ & $13.62 \mathrm{~A}$ \\
\hline US-704 & $22.57 \mathrm{C}$ & $17.46 \mathrm{~B}$ & $72.86 \mathrm{~B}$ & $10.74 \mathrm{D}$ & $10.89 \mathrm{C}$ \\
\hline $\mathrm{LSD} \leq 0.05 \mathrm{P}$ & 0.36 & 0.30 & 1.11 & 0.15 & 0.70 \\
\hline $\mathrm{TS} \times \mathrm{C}$ & NS & NS & NS & NS & NS \\
\hline
\end{tabular}

The mean values sharing different letters differed at $0.05 \%$ probability level.

The maximum plant height was noted in the $150 \mathrm{~cm}$ apart trench and maximum cane length was observed in $120 \mathrm{~cm}$ apart trenches and the minimum was observed in the $90 \mathrm{~cm}$ spaced trenches. The taller and thicker plants in wider spacing attributed to better use of light and circulation of air which resulted in more assimilate production owing to improvement in the process of photosynthesis. The better production of assimilates in wider spacing was responsible for the production of taller and thicker plants as compared to narrow spacing. Earlier different authors also noticed the taller plants in wider row spaces compared to narrow row spaces (Yadav, 2004; Maqsood et al., 2005). Similarly, trench spacing also significantly influenced the un-stripped and SCY. The higher un-stripped cane yield in wider space can be due to more millable canes, cane length, cane diameter and cane top weight. Likewise, Cheema et al. (2002) also obtained the higher un-stripped cane yield with wider spacing compared to narrow spaces. The higher cane yield in $120 \mathrm{~cm}$ apart trenching was due to the production of taller canes with more stripper cane weight. These findings are the same as reported by Bashir et al. (2005) they described that wider row spacing considerably increased the stripped cane yield.

Clones also had differential responses for growth and yield. The maximum plant height was observed in US127, while maximum cane length and millable cane were observed in US-272. The difference amongst the clones for plant height and cane length can be ascribed to differences in their genetic potential 
for plant height, cane length and millable canes. Likewise, clones also had significant differences for the un-stripped cane yield and SCY. Clone US-127 had maximum un-stripped cane yield and SCY which can be attributed to taller canes with more weight per striped cane as compared to other clones. Previously, Islam et al. (2011) also observed the considerable differences among clones for the cane length, cane yield and sugar yield.

Trench spacing had a non-significant effect on the brix, SC, CJP and CCS (Table 3). These outcomes are similar with the result of Chattha (2007) and Khan et al. (2003) they also noted the non-significant effect of planting spaces on the brix, SC, CJP and CCS. Moreover, trench spacing significantly influenced the total sugar yield with maximum total sugar yield was noted in $120 \mathrm{~cm}$ apart trenches. The maximum cane length and SCY were responsible for the maximum sugar yield in $120 \mathrm{~cm}$ spaced planting patterns. Previous studies of Sundara (2002) and Chattha (2007) also noted that planting patterns significantly affected the total sugar yield. Clones US-127 had maximum brix, SC, CJP, CCS and total sugar yield. The clone US-127 had minimum bagasse contents therefore, it had maximum brix, SC, CJP, and CCS as compared to other clones. Moreover, the highest cane length, SCY was responsible for the maximum sugar yield in US-127 as compared to the other cultivars. Previously, Islam et al. (2011) reported that cultivars differed, for brix percentage, sugar recovery and sugar yield.

\section{Conclusions and Recommendations}

In conclusion, planting in $120 \mathrm{~cm}$ apart trenches performed appreciably well with maximum stripped cane yield and total sugar yield as compared to other trench spacing. In the case of clones, US-272 produced maximum stripped cane yield however, US127 produced maximum cane yield and sugar yield owing to maximum sugar recovery.

\section{Novelty Statement}

The ratooning potential of promising sugarcane clones under different trench spacing was not explored. Therefore, this study was conducted to determine the ratooning potential of different promising sugarcane clones under different trench spacing.

\section{Author's Contribution}

RiazAhmad: Conceived and designed the experiment. Muhammad Aman Ullah Khan: Performed the experiment.

Muhammad Aman Ullah, Muhammad Talha Aslam and Abdul Rehman: Data collection.

Muhammad Aman Ullah and Muhammad Umair Hassan: Writing original draft.

Muhammad Nawaz, Muhammad Jahanzaib Khan, Muhammad Ahsin Ayub, Arbaz Ahmad Khan, Muhammad Adil Rehman, Bilal Ahmad Shahzad and Sajid Hussain: Reviewing and editing.

Conflict of interest

The authors have declared no conflict of interest.

\section{References}

Aamer, M., Ahmad, R., Anjum, S.A., Hassan, M.U., Rasul, F., Zhiqiang, W., Qasim, H.Z.U., Chaudhary, F.A. and Guoqin, H., 2017. Production potential of ratoon crop of sugarcane planted under varying planting dimensions. Academia Journal of Agricultural Research, 5(3): 39-44.

Bashir, S., Chattha, A.A., Yasin, M. and Mahmood, Z., 2005. Sugarcane varieties and row spacing effect on sugarcane traits. Pakistan Sugar Journal, 20(2): 18-20.

Bhullar, M.S., Thind, K.S., Uppal, S.K. and Singh, K., 2008. Productivity, profitability and quality of sugarcane (Saccharum officnarum spp.) plant-ratoon system in relation to planting methods and seeding rate. Indian Journal of Agronomy, 53(3): 195-199.

Chattha, M.U., 2007. Studies on growth, yield and quality of sugarcane (Saccharum officinarum L.) under different planting techniques, irrigation methods, water levels and mulch types (Doctoral Dissertation, University of Agriculture, Faisalabad Pakistan).

Chattha, M.U., Hassan, M.U., Khan, I., Bilal, M., Chattha, M.A., Nawaz, M., Anjum, S.A., Ashraf, U. and Kharal, M., 2020. Impact of planting methods on biomass production, chemical composition and methane yield of sorghum cultivars. Pakistan Journal of Agriculture Sciences, 57(1): 43-51.

Chattha, M.U., Hassan, M.U., Khan, I., Chattha, M.B., Munir, H., Nawaz, M., Mahmood, A., 
Usman, M. and Kharal, M., 2017a. Alternate skip irrigation strategy ensure sustainable sugarcane yield. Journal of Animal and Plant Sciences, 27(5): 1604-1610.

Chattha, M.U., Iqbal, A., Hassan, M.U., Chattha, M.B., Ishaque, W.,Usman, M., Khan, S., Fayyaz, M.T. and Ullah, M.A., 2017. Forage yield and quality of sweet sorghum as influenced by sowing methods and harvesting times. Journal of Basic and Applied Sciences, 13: 301-306. https:// doi.org/10.6000/1927-5129.2017.13.49

Cheema, I.A., Ayub, M. and Jabbar, A., 2002. Morphological response of spring planted sugarcane to spaced arrangement and nutrient management. Pakistan Sugar Journal, 17(6): 6268.

Ehsanullah, K.J., Jamil, M. and Ghafar, A., 2011. Optimizing the row spacing and seeding density to improve yield and quality of sugarcane. Crop and Environment, 2(1): 1-5.

FAO Stat. 2017. Statistical Database. Food and Agriculture Organization (FAO). Available online: at www.faostat.fao.org. (verified on 1211-2017).

GoP, 2017. Pakistan economic survey 2016-17. Ministry of food agriculture and livestock, federal bureau of Stat. Islamabad. pp. 20.

GoP, 2020. Pakistan economic survey 2019-20. Ministry of food agriculture and livestock, federal bureau of Stat. Islamabad. pp: 20.

Hassan, M.U., Chattha, M.U., Barbanti, L., Chattha, M.B., Mahmood, A., Khan, I. and Nawaz, M., 2019b. Combined cultivar and harvest time to enhance biomass and methane yield in sorghum under warm dry conditions in Pakistan. Industrial Crops and Products, 132: 84-91. https://doi.org/10.1016/j. indcrop.2019.02.019

Hassan, M.U., Chattha, M.U., Barbanti, L., Mahmood, A., Chattha, M.B., Khan, I., Mirza, S., Aziz, S.A., Nawaz, M. and Aamer, M., 2020. Cultivar and seeding time role in sorghum to optimize biomass and methane yield under warm dry climate. Industrial Crops and Products, 145: 111983. https://doi. org/10.1016/j.indcrop.2019.111983

Hassan, M.U., Chattha, M.U., Chattha, M.B., Mahmood, A. and Sahi, S.T., 2019a. Chemical composition and methane yield of sorghum as influenced by planting methods and cultivars. The Journal of Animal and Plant
Sciences, 29(1): 251-259.

Hassan, M.U., Chattha, M.U., Mahmood, A. and Sahi, S.T., 2018. Performance of sorghum cultivars for biomass quality and biomethane yield grown in semi-arid area of Pakistan. Environmental Science and Pollution Research, 25(13): 12800-12807. https://doi. org/10.1007/s11356-018-1575-4

Heerden, P.D., Singels, A., Paraskevopoulos, A. and Rossler, R., 2015. Negative effects of lodging on irrigated sugarcane productivity: An experimental and crop modelling assessment. Field Crops Research, 180: 135-142. https://doi.org/10.1016/j.fcr.2015.05.019

Homer, D.C. and Pratt, P.F., 1961. Methods of analysis for soils, plants and waters. Davis: University of California, Davis.

Islam, M.S., Miah, M.A.S., Begum, M.K., Alam, M.R. and Arefin, M.S., 2011. Growth, yield and juice quality of some selected sugarcane clones under water-logging stress condition. World Journal of Agricultural Sciences, 7(4): 504-509.

Khan, M.A., Keerio, H.K., Junejo, S., Panhwar, R.N., Aslam Rajput, M., Memon, Y.M. and Qazi, B.R., 2003. Evaluation of new sugarcane genotypes developed through fuzz correlation of cane yield and yield components. Journal of Animal and Poultry Sciences, 3(4): 270-273. https://doi.org/10.3923/jas.2003.270.273

Lal, M. and Singh, A.K., 2008. February. Multiple ratooning for high cane productivity and sugar recovery. In Proceedings of National Seminar on varietal planning for improving productivity and sugar recovery in sugarcane held at GBPUA \& T. Pantnagar, 14: 62-68.

Maqsood, M., Iqbal, M. and Tayyab, M., 2005. Comparative productivity performance of sugarcane (Saccharum officinarum L.) sown in different planting patterns at farmer's field. Pakistan Journal of Agricultural Sciences, 42(3-4): 25-28.

Nawaz, M., Chattha, M.U., Chattha, M.B., Ahmad, R., Munir,H., Usman, M., Hassan, M.U., Khan, S. and Kharal, M., 2017. Assessment of compost as nutrient supplement for spring planted sugarcane (Saccharum officinarum L.). The Journal of Animal and Plant Sciences, 27(1): 283293.

Nawaz,M., Shahbaz K.,Hakoomat A., Muhammad I., Muhammad UC., Muhammad U.H., Sohail I., Shabir H., and Sadia K., 2019. Assessment 
of environment-friendly usage of spent wash and its nutritional potential for sugarcane production. Communications in Soil Science and Plant Analysis, 50: 1239-1249. https://doi.org/ 10.1080/00103624.2019.1614601

Shukla, S.K., Lal, M. and Singh, S.K., 2013. Improving bud sprouting, growth and yield of winter initiated sugarcane ratoon through tillage cum organic mediated rhizospheric modulation in Udic ustochrept under subtropical Indian condition. Soil and Tillage Research, 126: 50-59. https://doi.org/10.1016/j.still.2012.07.016

Singh, P.K. and Dey, P., 2002. Genetic variability in plant and ratoon of sugarcane genotypes grown under saline conditions. Indian Sugar, 51(10): 725-727.

Spancer, G.L. and G.P. Meade. 1963. Cane sugar hand book. $9^{\text {th }}$ Ed. G.P. Meade. John Wiley and Sons, Inc. New York. pp. 17.

Steel, R.G. and Torrie, J.H., 1997. Principles and procedures of statistics: A biometrical approach. McGraw-Hill.

Sundara, B., 2002. Influence of varieties, seed and fertilizer rates and planting patterns on sugarcane (Saccharum officinarum) grown under wide row spacing. Indian Sugar, 52(5): 341-347.

Ullah, S., Anjum, S.A., Raza, M.M., Riaz, A., Abbas, A., Yousif, M.M., Ma, J., Liu, Y., Zhang, J., Cheng, D. and Xu, Y., 2016. Optimizing row spacing to ameliorate the productivity of spring sugarcane (Saccharum officinarum L.). Agricultural Sciences, 7: 531-538. https:// doi.org/10.4236/as.2016.78053

Yadav, R.L., 2004. Enhancing efficiency of fertilizer $\mathrm{n}$ use in sugarcane by ring-pit method of planting. Sugar Technology, 6(3):169-171.very in sugarcane held at GBPUA \& T. Pantnagar, 14: 62-68. https://doi.org/10.1007/BF02942719

Maqsood, M., Iqbal, M. and Tayyab, M., 2005. Comparative productivity performance of sugarcane (Saccharum officinarum L.) sown in different planting patterns at farmer's field. Pakistan Journal of Agricultural Sciences, 42(3-4): 25-28.

Nawaz, M., Chattha, M.U., Chattha, M.B., Ahmad, R., Munir, H., Usman, M., Hassan, M.U., Khan,
S. and Kharal,M., 2017.Assessment of compost as nutrient supplement for spring planted sugarcane (Saccharum officinarum L.). The Journal of Animal and Plant Sciences, 27(1): 283293.

Nawaz,M., Shahbaz K.,Hakoomat A.,Muhammad I., Muhammad UC., Muhammad U.H., Sohail I., Shabir H., and Sadia K., 2019. Assessment of environment-friendly usage of spent wash and its nutritional potential for sugarcane production. Communications in Soil Science and Plant Analysis, 50: 1239-1249. https://doi.org/ 10.1080/00103624.2019.1614601

Shukla, S.K., Lal, M. and Singh, S.K., 2013. Improving bud sprouting, growth and yield of winter initiated sugarcane ratoon through tillage cum organic mediated rhizospheric modulation in Udic ustochrept under subtropical Indian condition. Soil and Tillage Research, 126: 50-59. https://doi.org/10.1016/j.still.2012.07.016

Singh, P.K. and Dey, P., 2002. Genetic variability in plant and ratoon of sugarcane genotypes grown under saline conditions. Indian Sugar, 51(10): 725-727.

Spancer, G.L. and G.P. Meade. 1963. Cane sugar hand book. $9^{\text {th }}$ Ed. G.P. Meade. John Wiley and Sons, Inc. New York. pp. 17.

Sundara, B., 2002. Influence of varieties, seed and fertilizer rates and planting patterns on sugarcane (Saccharum officinarum) grown under wide row spacing. Indian Sugar, 52(5): 341-347.

Steel, R.G. and Torrie, J.H., 1997. Principles and procedures of statistics: A biometrical approach. McGraw-Hill.

Ullah, S., Anjum, S.A., Raza, M.M., Riaz, A., Abbas, A., Yousif, M.M., Ma, J., Liu, Y., Zhang, J., Cheng, D. and Xu, Y., 2016. Optimizing row spacing to ameliorate the productivity of spring sugarcane (Saccharum officinarum L.). Agricultural Sciences, 7: 531-538. https:// doi.org/10.4236/as.2016.78053

Yadav, R.L., 2004. Enhancing efficiency of fertilizer $\mathrm{n}$ use in sugarcane by ring-pit method of planting. Sugar Technology, 6(3): 169-171. https://doi.org/10.1007/BF02942719 